\title{
RESENHA DA TEORIA CRÍTICO-ESTRUTURALISTA DO DIREITO COMERCIAL, DE CALIXTO SALOMÃO FILHO
}

\section{REVIEW OF TEORIA CRÍTICO-ESTRUTURALISTA DO DIREITO COMERCIAL, BY CALIXTO SALOMÃO FILHO, 2015}

\author{
Vinicius Figueiredo Chaves \\ Universidade Federal Fluminense - UFF - (Volta Redonda, RJ, Brasil) \\ Universidade Federal do Rio de Janeiro - UFRJ - (RJ, Brasil) \\ Universidade Estácio de Sá (RJ, Brasil)
}

Recebimento: 3 jul. 2017

Aceitação: 24 ago. 2017

\begin{abstract}
Como citar esta resenha / How to cite this review (informe a data atual de acesso / inform the current date of access):
\end{abstract}

CHAVES, Vinicius Figueiredo. Resenha da Teoria crítico-estruturalista do Direito Comercial, de Calixto Salomão Filho. Revista da Faculdade de Direito UFPR, Curitiba, PR, Brasil, v. 62, n. 3, p. 349-355, set./dez. 2017. ISSN $2236-7284$. Disponível em: <http://revistas.ufpr.br/direito/article/view/53662>. Acesso em: 21 dez. $2017 . \quad$ DOI: http://dx.doi.org/10.5380/rfdufpr.v62i3.53662.

\section{PALAVRAS-CHAVE}

Direito comercial. Transformações econômicas e sociais. Teoria crítico-estruturalista. Dispositivos declaratórios de interesses.

\section{KEYWORDS}

Commercial law. Economical and social changes. Critical structuralist theory. Declaratory interest devices.

Em sua Teoria crítico-estruturalista do Direito Comercial, Calixto Salomão Filho, professor titular de Direito Comercial da Universidade do Estado de São Paulo (USP), busca resgatar (e renovar) uma tradição do pensamento crítico no Direito Comercial. Segundo relata, essa tradição teria surgido na Faculdade de Direito da USP, nas décadas de 70 e 80, por intermédio dos trabalhos de autores como Modesto Carvalhosa e Fábio Konder Comparato, que, respectivamente, analisaram (criticamente) o anteprojeto e a posterior lei das sociedades por ações - Lei 6.404/76 - e a função social dos bens de produção.

Na teoria ventilada por Salomão Filho, a retomada e renovação (baseada em inovações e reformulações) da ideia de pensamento crítico em Direito Comercial vêm associadas ao referencial teórico-metodológico do estruturalismo jurídico, apresentado pelo autor como uma alternativa para o 
Direito (em especial, o Direito Comercial) ${ }^{1}$. Direito que, nas suas palavras, encontra-se num estado de letargia que já dura mais de 300 anos, período em que se consolidou muito mais como um instrumento de manutenção das estruturas (econômicas, especialmente) existentes, do que propriamente como um Direito transformador da realidade.

Ao lançar os olhos sobre o Direito, o autor parte da constatação (crítica, repita-se) de que este talvez seja, ultimamente, o ramo do conhecimento social que "mais de perto e com mais intensidade venha sentindo e se submetendo aos desígnios de outras ciências sociais” (SALOMÃO FILHO, 2015, p. 253) - a Economia principalmente. De acordo com esta visão, o Direito tem assistido, passivamente, à formação (e contribuído, portanto, para a manutenção) histórica de estruturas econômicas desestabilizadoras do sistema jurídico, "exatamente porque levam à determinação das normas de conduta por padrões de poder e não por valores”.

As reações dele a estas concepções (que ele aponta como dominantes no Direito em geral) são particularmente voltadas para os dois ramos do Direito que lidam mais diretamente com a organização e disciplina jurídica da atividade econômica, isto é, o Direito Econômico e o Direito Comercial. Tais disciplinas em geral (e alguns de seus institutos, em particular), marcadas pela força determinante das estruturas de poder econômico formadas ao longo da história, são então postas em perspectiva crítica, conectadas por um ponto central: o reconhecimento, em ambos os casos, da necessidade de mudanças estruturais baseadas numa revisão do funcionamento do sistema econômico por intermédio do Direito².

Algumas destas estruturas desestabilizadoras denunciadas por Salomão Filho (2015), associadas ao conservadorismo que lhes permite manter as vigas de sustentação, encontram-se particularmente presentes no Direito Comercial contemporâneo - no Direito brasileiro, inclusive -, campo do conhecimento em que se tem verificado a aceitação e até mesmo a valorização do poder econômico. Esse ramo da ciência jurídica, relata o autor, tem sido marcado por um quadro sombrio que se caracteriza como uma verdadeira disfunção, na medida em que simultaneamente: i) “vem associado à manutenção das estruturas e conservadorismo, mesmo em uma época em que o sistema

\footnotetext{
${ }^{1}$ De acordo com o autor (SALOMÃO FILHO, 2015, p. 259-261), a opção pela utilização da expressão estruturalismo diz respeito mais a uma razão de conteúdo (identificação, crítica e transformação das estruturas econômicas e jurídicas associadas a relações de poder e de dominação, que acabam por conduzir à determinação das normas jurídicas por poder e não por valores) do que a uma razão histórica (ligação a uma teoria anterior igualmente denominada). O estruturalismo proposto opõe-se à teoria dos sistemas, na medida em que não vê no Direito (e na teoria do Direito) um sistema autorreferencial e programável com base unicamente em seus princípios e funcionamento interno próprios. A partir dessa perspectiva, identificar, criticar e propor transformar tais estruturas não implica construir um sistema.

${ }^{2}$ Veja-se que, aqui, a proposta (Direito transformador da realidade econômica e social) se apresenta como diametralmente oposta a perspectivas como a exposta por Rachel Sztajn (2010), para quem o Direito apenas reconhece e convalida mudanças, não as produz.
} 
capitalista tão gritantemente clama por mudanças de fundo"; e ii) "vem sendo reduzido a uma mesmice pragmática em que chavões de homens de negócios são incorporados pelo meio jurídico e reproduzidos com princípios jurídicos que devem ser constantemente repetidos” (SALOMÃO FILHO, 2015, p. 7).

Diante de tais constatações, Salomão Filho procura resgatar (como ele próprio assinala na introdução de sua Teoria crítico-estruturalista do Direito Comercial) e renovar uma perspectiva do conhecimento em que o Direito Comercial ganha importância e sentido novos, posicionando-se não como passivo observador e receptor de dados do cotidiano econômico-empresarial, mas sim como um instrumento de transformações econômicas e sociais. Passa a se preocupar, também, com a transformação de dados econômicos em valores e, assim, a influenciar o próprio conhecimento da vida econômica empresarial.

As origens e fundamentos do estado de letargia do Direito - decorrente de sua submissão ao poder econômico - são explicitados pelo autor em breve percurso histórico, que remonta ao surgimento da perspectiva do racionalismo jurídico, com sua transição ao positivismo jurídico.

Salomão Filho (2015, p. 29) inicia a sua análise pela denominada fase de ruptura interna da ciência jurídica, oriunda do movimento epistemológico conhecido como racionalismo jurídico. Essa ruptura, que teve em Samuel Pufendorf o seu representante mais influente, pode ser entendida como uma cisão entre moral e Direito, que se opera quando o fundamento deste passa a repousar na lógica, e não em algum elemento religioso ou ético. Tem-se, deste modo, um sistema racional e autointegrado de disciplina das relações sociais.

O autor aponta que essas duas características, a busca da racionalidade científica e a autointegração, desde então passaram a acompanhar os ordenamentos jurídicos ocidentais (de Direito codificado) até os dias atuais. No primeiro caso, a criação e interpretação do Direito passam a objetivar fundamentalmente a demonstração lógica, em substituição ao método exegético-histórico. Por seu turno, a segunda característica contém a aposta na crença de que tal método (lógico) possibilita a solução de todas as situações da vida social (SALOMÃO FILHO, 2015, p. 29).

Este movimento de concentração do Direito em torno de esquemas lógico-formais, aliado à afirmação da autossuficiência do sistema jurídico, teria conduzido ao seu fechamento em torno de si mesmo, pavimentando o caminho para o surgimento do positivismo dogmático no século XIX, estabelecido sobretudo na Alemanha por meio da Pandectística. No sistema racionalista-pandectista, “a lógica substitui o conceito de justiça, determinando-o” (SALOMÃO FILHO, 2015, p. 29).

Com a promulgação do Código Civil alemão, o Bürgerliches Gesetzbuch (BGB, 1900), o chamado positivismo jurídico (já estabelecido em outros países, notadamente na França) se consolida 
e, nas palavras de Salomão Filho (2015, p. 29-30), passa a dominar a cena dos países de Civil Law, reforçando ainda mais as "elucubrações lógicas e racionais, cada vez mais distante de valores e seus princípios”, e pavimenta o caminho para a “submissão do Direito aos desígnios técnicos de outras ciências”.

A partir de então, “a afirmação e prevalência do movimento positivista têm enorme efeito sobre a afirmação e prevalência da ideia do poder econômico no campo do direito” (SALOMÃO FILHO, 2015, p. 30). Em meio a esta lógica de exacerbação da racionalidade, o Direito passa a ser visto como instrumento para consecução de objetivos econômicos.

De fato, os contornos da teoria desenvolvida pelo professor Calixto Salomão Filho (2015) ${ }^{3}$, por seu perfil e fundamentação crítico-estruturalista, dão suporte à elaboração de estudos e reflexões que tenham como finalidade a revisão de concepções tradicionais enraizadas no Direito Comercial brasileiro. Em consequência, apresenta-se como base de sustentação de reflexões críticas e, o que é mais importante, de edificação de conteúdos propositivos alternativos, sempre direcionados à transformação das estruturas no bojo das quais é possível detectar traços marcantes da influência dos determinismos econômicos no Direito.

Segundo Salomão Filho (2014), a contribuição do Direito, no que tange à implementação de uma agenda progressista e transformadora da realidade econômica e social, depende da intervenção legislativa direta sobre determinadas estruturas econômicas (e nos institutos jurídicos que as protegem). Não no sentido de uma tentativa de planejamento ou definição dos resultados do processo econômico (que seria inútil), mas sim com a finalidade de proteger valores que são instrumentais à construção de um modelo mais amplo de um devido processo econômico, voltado ao desenvolvimento em seu sentido real, ou seja, econômico e social (e não somente à proteção dos interesses daqueles que exercem o domínio sobre os bens de produção).

A partir dessa perspectiva de mudança de método, uma das propostas esboçadas por Salomão Filho (2014) reside na elaboração ou identificação de dispositivos declaratórios de interesses, para a adequada consideração e sopesamento dos interesses envolvidos pela aplicação do Direito Comercial. Trata-se de uma intervenção de natureza estrutural, com a finalidade de se estabelecer determinados interesses que devem ser respeitados ou ao menos considerados na disciplina jurídica do Direito Comercial.

\footnotetext{
${ }^{3}$ Aqui, repete-se a expressão teoria inserida no título da obra. Conforme exposição do próprio autor, muito embora não se trate de uma obra que buscou a completude de temas, a inclusão deste termo no título se justifica em função da coesão metodológica em torno da crítica das estruturas que emperram ou limitam as mudanças no Direito Comercial.
} 
A visão crítico-estruturalista de Salomão Filho é alicerçada numa matriz epistemológica de pensamento baseada numa concepção em que o Direito é entendido como um instrumento de transformações econômicas e sociais, impulsionado por uma teoria jurídica do conhecimento econômico e social. De acordo com esta acepção ${ }^{4}$, os valores da sociedade, democraticamente estabelecidos, precisam influenciar tanto os processos de edificação de escolhas normativas (inclusive, no que diz respeito à configuração ou reconfiguração de institutos jurídicos) como também as interpretações atinentes ao Direito Comercial $^{5}$.

Na teoria jurídica do conhecimento econômico e social os dispositivos declaratórios de interesses são apresentados como um terceiro tipo ou categoria de norma jurídica (SALOMÃO FILHO, 2015), ao lado das tradicionais princípios e regras ${ }^{6}$ (segundo a classificação mais comumente adotada pela doutrina).

Nesta nova classificação o gênero norma jurídica seria então composto por princípios e regras ${ }^{7}$, e dispositivos declaratórios de interesses.

Os dispositivos declaratórios, nesta perspectiva, consistem em um novo instrumento normativo voltado à enumeração (reconhecimento e proteção) de interesses envolvidos por um determinado princípio ou regra. Adicionalmente, as doravante chamadas normas-dispositivos se apresentam também como determinantes para a interpretação das demais, isto é, as normas-princípios ou normas-regras de Direito Comercial a ele relacionadas (SALOMÃO FILHO, 2014).

Isso significa que, para além da enumeração dos interesses envolvidos, tais dispositivos declaratórios, ao lado dos princípios, devem se constituir igualmente como guias interpretativos para o restante da legislação específica sobre determinadas áreas ${ }^{8}$. De acordo com este raciocínio, ditas normas jurídicas não devem se revestir de caráter genérico e geral - editadas para aplicação em uma generalidade de áreas (ex.: teoria geral da empresa e teoria dos títulos de crédito, simultânea e indistintamente) -, sendo sua utilidade proporcional ao grau de especificidade (ex.: teoria geral da

\footnotetext{
${ }^{4}$ Dentro da classificação exposta por Norberto Bobbio (2006), defende-se o enquadramento da teoria jurídica do conhecimento econômico e social como uma concepção filosófica - valorativa e deontológica -, por ser dotada de uma estrutura teleológica que entende o Direito como um ordenamento destinado a realizar certos fins-valores (no caso, transformações econômicas e sociais).

${ }^{5}$ Portanto, defende-se aqui o instrumentalismo econômico, não o jurídico.

${ }^{6}$ Tal como adverte Virgílio Afonso da Silva (2003, p. 607), “o conceito de norma jurídica e a discussão sobre suas espécies são temas de infindáveis controvérsias e os juristas parecem ter uma grande dificuldade para chegar ao menos perto de algum denominador comum acerca do objeto de sua disciplina”.

${ }^{7}$ Sobre a classificação das normas como gênero, do qual seriam espécies as regras e os princípios, ver TAVARES (2010, p. 406). Vale, igualmente, destacar a posição de Lenio Luiz Streck (2012), para quem as normas consistem num conceito interpretativo e a normatividade emerge, na verdade, de um quadro factual constituído por regras e princípios.

${ }^{8}$ Salomão Filho (2014) manifesta interessante posição no que diz respeito à forma de implementação destas medidas (dispositivos declaratórios), sugerindo que elas ocorram não por intermédio de um código, mas sim mediante regulamentos ou leis específicas, contendo apenas os dispositivos e os princípios aplicáveis.
} 
empresa, somente) possível de ser alcançado (SALOMÃO FILHO, 2014) em seus textos e conteúdos normativos $^{9}$.

O professor Salomão Filho não avançou no aprofundamento de questões específicas sobre todas as diversas subáreas do Direito Comercial. Ao contrário, já na introdução da sua obra destacou que ela se caracterizava por apontamentos gerais, e que ali não se esgotava. A ideia anunciada em seu título, Revisão crítico-estruturalista..., acaba por destinar-se mais a um projeto geral de resgate da tradição e introdução de inovação no pensamento crítico em Direito Comercial e, em paralelo, à consolidação de uma escola dotada de presente, passado e futuro.

Apresenta-se como uma base teórico-metodológica para raciocínios críticos, reflexivos e propositivos, voltada para aprofundamentos dos estudos e compreensões sobre temas delimitados cujo propósito maior reside na construção de um Direito Comercial simultaneamente organizador da sociedade e transformador de suas estruturas (criticar, revisar e transformar). Portanto, um Direito entendido como instrumento de transformações econômicas e sociais.

Nesta trajetória de crítica e revisão estruturalista de institutos do Direito Comercial, não se aceita a vinculação estrita à dogmática jurídica (aqui entendida como perspectiva estritamente jurídica e formalista), assim como não se acolhe a integração interdisciplinar do Direito unicamente para com a economia (que tem resultado, em muitos sentidos, na assunção pura e simples das lições econômicas e, em última análise, na determinação das normas de conduta com base em padrões ditados pelos economistas).

\section{REFERÊNCIAS}

BOBBIO, Norberto. O positivismo jurídico: lições de filosofia do direito. Compilação Nello Morra. Tradução e notas Márcio Pugliesi. São Paulo: Ícone, 2006.

SALOMÃO FILHO, Calixto. Regulamentação da atividade empresarial para o desenvolvimento. Revista de Estudios Brasileños (REB), v. 1, n. 1, p. 45-54, 2014. Disponível em: <https://goo.gl/gnFmZh>. Acesso em: 13 mar. 2017.

SALOMÃO FILHO, Calixto. Teoria crítico-estruturalista do Direito Comercial. São Paulo: Marcial Pons, 2015.

SILVA, Virgílio Afonso da. Princípios e regras: mitos e equívocos acerca de uma distinção. Revista Latino-Americana de Estudos Constitucionais, v. 1, p. 607-630, 2003. Disponível em: <https://goo.gl/3Z5pFq>. Acesso em: 13 mar. 2017.

\footnotetext{
${ }^{9}$ Sobre a relação (e as diferenças) entre texto e norma, remete-se o leitor a STRECK (2014).
} 
STRECK, Lenio Luiz. A relação "texto e norma" e a alografia do direito. Revista Novos Estudos Jurídicos - Eletrônica, v. 19, n. 1, p. 2-20, jan./abr. 2014. Disponível em: <https://goo.gl/SCXxDZ>. Acesso em: 14 mar. 2017.

STRECK, Lenio Luiz. Diálogos (neo)constitucionais (Posfácio). In: OTTO, Écio; POZZOLO, Susanna. Neoconstitucionalismo e positivismo jurídico: as faces da teoria do direito em tempos de interpretação moral da Constituição. Florianópolis: Conceito, p. 171-218, 2012.

SZTAJN, Rachel. Teoria jurídica da empresa: atividade empresária e mercados. 2. ed. São Paulo: Atlas, 2010.

TAVARES, André Ramos. Princípios constitucionais. In: MARTINS, Ives Gandra da Silva; MENDES, Gilmar Ferreira; NASCIMENTO, Carlos Valder (Coord.). Tratado de direito constitucional, v. 1. São Paulo: Saraiva, p. 396-432, 2010.

Vinicius Figueiredo Chaves

Doutor em Direito pela UERJ, na linha de pesquisa Empresa e Atividades Econômicas. Mestre em Direito Público e Evolução Social pela UNESA. Pós-graduado em Direito Empresarial pela FGV. Professor adjunto na Universidade Federal Fluminense, vinculado ao ICHS, departamento de Direito. Professor permanente no PPGD da UNESA. Professor adjunto na Universidade Federal do Rio de Janeiro. E-mail: viniciuschaves@gmail.com 